\title{
Production of Marker-Free Apple Plants Expressing the Supersweet Protein Gene Driven by Plant Promoter
}

\author{
Vadim Timerbaev 1,2,3*, Tatiana Mitiouchkina ${ }^{1,2,3}$, Alexander Pushin ${ }^{1,3}$ and \\ Sergey Dolgov ${ }^{1,2,3}$
}

'Laboratory of Expression Systems and Modification of the Plant Genome "Biotron", Branch of the Shemyakin-Ovchinnikov Institute of Bioorganic Chemistry, Russian Academy of Sciences, Pushchino, Russia, ${ }^{2}$ Laboratory of Plant Bioengineering, Nikita Botanical Gardens - National Scientific Center, Russian Academy of Sciences, Yalta, Russia, ${ }^{3}$ Laboratory of Plant Genetic Engineering, All-Russia Research Institute of Agricultural Biotechnology, Russian Academy of Sciences, Moscow, Russia

\section{OPEN ACCESS}

Edited by:

Humberto Prieto, Instituto de Investigaciones Agropecuarias (INIA), Chile

Reviewed by: Claudia Renate Stange, Universidad de Chile, Chile

Ann Maureen Callahan, Appalachian Fruit Research Station (ARS-USDA), United States

*Correspondence: Vadim Timerbaev timerbaev@gmail.com

Specialty section:

This article was submitted to Technical Advances in Plant Science, a section of the journal

Frontiers in Plant Science

Received: 31 October 2018 Accepted: 13 March 2019

Published: 29 March 2019

Citation:

Timerbaev V, Mitiouchkina T,

Pushin A and Dolgov S (2019) Production of Marker-Free Apple Plants Expressing the Supersweet

Protein Gene Driven by Plant Promoter. Front. Plant Sci. 10:388. doi: 10.3389/fp/s.2019.00388
The presence of antibiotic resistance and other marker genes in genetically modified plants causes concern in society because of perceived risks for the environment and human health. The creation of transgenic plants that do not contain foreign genetic material, especially that of bacterial and viral origin, largely alleviates the tension and makes the plants potentially more attractive for consumers. To produce marker-free transgenic apple plants, we used the pMF1 vector, which combines Zygosaccharomyces rouxii recombinaseR and a CodA-nptll bifunctional selectable gene. The thaumatin II gene from the tropical plant Thaumatococcus daniellii, which is under the control of the plant E8 gene (a predominantly fruit-specific promoter) and rbsS3A terminator, was taken as the gene of interest for modification of the fruit taste and enhancing its sweetness. Exploitation of this gene in our laboratory has allowed enhancing the sweetness, as well as improving the taste characteristics, of fruits and vegetables of plants such as strawberry, carrot, tomato and pear. We have obtained three independent transgenic apple lines that have been analyzed by PCR and Southern blot analyses for the presence of T-DNA sequences. Two of them contained a partial sequence of the T-DNA. With one line containing the full insert we then used a delayed strategy for the selection of marker-free plants. After induction of recombinase activity in leaf explants on selective media with 5-fluorocytosine (5-FC) we obtained more than 30 sublines, most of which lost their resistance to kanamycin. Most of the apple sublines showed the expression of the supersweet protein gene in a wide range of levels as detected by RNA accumulation. The plants from the group with the highest transcript level were propagated and grafted onto dwarf rootstocks for early fruit production for future estimates of protein levels and organoleptic analyses. Thus, we developed a protocol that allowed the production of marker-free apple plants expressing the supersweet protein.

Keywords: Agrobacterium-mediated transformation, marker-free plants, Malus $\mathrm{x}$ domestica, thaumatin II, cytosine deaminase, $\mathrm{R} / \mathrm{RS}$ recombination system 


\section{INTRODUCTION}

Despite the increase in the number of genetically engineered forms of plants and their evident economic expedience, such crops are quite cautiously accepted by society, primarily due to the presence of foreign genetic material from distant organisms (bacteria, viruses, etc.) for the expression of target genes in transgenic plants and as selective markers of resistance to antibiotics and herbicides. Under these conditions special urgency is given to techniques by which new highly productive forms of crops can be created without foreign genetic material, primarily of bacterial origin, and without genes of antibiotic resistance, the lack of which is probably to facilitate the release genetically modified organisms into open systems especially in regions with distrust related to GMO such as the European Union. For example, in 2010 Amflora potato, which has high amylopectin content, was approved for commercial cultivation in the EU. Amflora was criticized for the presence of the antibiotic resistance nptII gene. In 2011, BASF has stopped selling its Amflora potatoes in the EU due to widespread public and political resistance and finally variety was withdrawn from the EU market by the European Commission in 2013 due to procedural errors during the approval process (Kamle et al., 2017). The European Commission has stated in one of the report that cisgenic crops are becoming more accepted in Europe (Gaskell et al., 2013). To meet modern trends, some governments are implementing global projects with approaches to minimize foreign DNA in the genomes of commercial crops. From 2006 to 2015 Wageningen University and Research Centre carried out a project on Durable Resistance in potato against Phytophthora aimed at stimulating research on genetic modification and public debate on innovative genetic techniques like cisgenesis (Haverkort et al., 2016).

In recent years the use of alternative strategies that allow transformed cells to obtain an advantage (for example, the marker gene encodes an enzyme that converts a selective agent into the metabolically available form, or usage of alternative nutrient sources Sidorova et al., 2017) is gaining in popularity. Such systems are referred to as positive selection. In some cases, the use of positive selection can significantly improve the transformation frequency, but its main advantage lies in the absence of antibiotic resistance genes in resulting plants. The strategies for marker gene elimination from the nuclear genome are a fundamentally different approach. They include cotransformation of the transgenes with the subsequent segregation (Daley et al., 1998), removal of marker genes by means of transposons (Goldsbrough et al., 1993) and strategies based on site-specific recombination to allow the elimination of undesired DNA after appropriate treatment (Gleave et al., 1999). To date, three systems based on site-specific recombinase are well studied and described. These are the Cre/lox system of the P1 phage (Dale and Ow, 1991), the FLP/FRT recombinase system from Saccharomyces cerevisiae (Lyznik et al., 1996) and the R/RS recombinase system from Zygosaccharomyces rouxii (Onouchi et al., 1995; Sugita et al., 2000). One of the examples of markerfree technology development may be multi-auto-transformation vectors (MAT) (Ebinuma et al., 1997). The first systems were based on the visual selection of transgenic plants containing ipt or rol oncogenes (Ebinuma et al., 1997; Ebinuma and Komamine, 2001). Thus, the use of oncogenes as selective agents allows easy visual selection of transformed tissues; however, obtaining transgenic plants with a normal phenotype requires the removal of the oncogenes from the genome. In the first MAT systems, the deletion of these genes was carried out using inverted repeats of the transposon $A c$ from maize; the frequency of loss of the ipt marker gene was very low, however $(0.1-0.5 \%)$. Later, the R/RS recombination system began to be used to remove the marker gene (Sugita et al., 1999, 2000), whereby the removal efficiency has been improved significantly, but initially the elimination of foreign sequences occurred spontaneously in MAT systems due to the constitutive expression of recombinase, which made the process uncontrollable, and led to unpredictable results. An additional increase in the frequency of marker gene-free transgenic lines was achieved by the use of a dexamethasoneinducible expression system to remove the marker gene ipt (Kunkel et al., 1999). After selection of the transformants, the chemical activation of recombinase leads to elimination of the unnecessary portion of T-DNA from a plant genome. Despite the wide use of these vectors to produce transgenic plants of different species, not very many studies have been devoted to obtaining marker-free plants with beneficial features.

Since the methods of obtaining marker-free organisms have acquired special relevance only in the last decade, most of the studies are devoted to the development of new technologies and vector systems. In this work, to remove the undesirable DNA we used a site-specific recombinase belonging to the pMF vectors (Plant Research International, Wageningen, Netherlands) (Schaart et al., 2004). The main advantage of this system is its sequential double selection. The first stage after Agrobacteriummediated transformation is the selection of regenerants by using antibiotics such as kanamycin, hygromycin, or phosphinotricine, and further elimination of DNA sequences, flanked by the intact recombination sites (RS) occurs as a result of the chemical activation of recombinase $\mathrm{R}$ that is inactivated in the presence of the ligand-binding domain (LBD) of a glucocorticoid receptor. Its activation is carried out after incubation of the plant tissue in a solution of dexamethasone (Dex). Further selection on a medium with 5-fluorocytosine (5-FC) prevents the development of plant tissues containing the $\operatorname{cod} A$ gene (cytosine deaminase converts non-toxic 5-FC to cytotoxic 5-fluorouracil); it thus becomes impossible to obtain chimeras due to incomplete elimination of the DNA. This system was successfully applied in cultures such as strawberries, apples, and pears (Schaart et al., 2004; Vanblaere et al., 2011; Righetti et al., 2014; Krens et al., 2015).

Based on pMF1 vector we created a plasmid containing the gene for supersweet thaumatin II protein under the control of the fruit-specific E8 gene promoter and rbsS3A gene terminator. Thaumatin II was first isolated from the fruits of the tropical plant katemfe (van der Wel and Loeve, 1972); it is 3000 times sweeter than sucrose (Nikoleli and Nikolelis, 2012). The thaumatin threshold value of sweetness in humans is $50 \mathrm{nM}$, one of the lowest of any sweet-tasting protein. The perception of sweetness is delayed to some extent and it leaves a slight liquorice-like after-taste (Nairn et al., 1986). Moreover, thaumatin II has an 
anti-fungal activity (Vigers et al., 1992; Popowich et al., 2007), so in addition to improving the taste of fruits of agricultural crops the heterologous expression of the thaumatin II gene makes it possible to increase the resistance of these plants to fungal phytopathogens. In the first studies with the thaumatin II gene, potatoes (Witty, 1990) and cucumber (Szwacka et al., 1996) plants were used as objects. Expression of the thaumatin II gene in transgenic cucumber causes not only a sweeter taste, but also higher aroma acceptability (Szwacka et al., 1996). Presently, a wide range of cultures expressing this supersweet protein has been obtained including strawberries, carrots, pears, and others (Schestibratov and Dolgov, 2005; Dolgov et al., 2011; see reviews by Szwacka et al., 2012 and Firsov et al., 2018). In the fruits of these plants a recombinant protein was detected and a modification of the taste was observed increasing their sweetness and attractiveness. Increasing the sweetness of apple fruit is an actual problem in temperate climates, like in Russia. In the cultures listed above, control of thaumatin II gene expression is controlled by the $35 \mathrm{~S}$ virus promoter and the plant genome contains selective genes. For breeding purposes it is desirable to produce plants that lack the antibiotic resistance genes and display fruit-specific expression of the thaumatin II gene. For this, we used one of the well-characterized promoters of the tomato E8 gene. Transcription of E8 gene is activated at the onset of fruit ripening (Deikman et al., 1992), so promoter of E8 gene reported as fruit-ripening specific.

The objective of this study was to obtain marker-free apple plants with the gene for supersweet protein thaumatin II under control of plant fruit-specific promoter and conduct analysis of its expression in the transgenic plants.

\section{MATERIALS AND METHODS}

\section{Creation of a Binary Vector}

The binary plasmid pMF-E8 is based on pMF1 (Schaart et al., 2004) was used for the Agrobacterium-mediated transformation of apple plants. The coding sequence of thaumatin II gene was obtained by PCR from plasmid pUR528 containing a fragment of preprothaumatin II (Edens et al., 1982) using primers Thau-CDS (Table 1). An $1195 \mathrm{bp}$ fragment of tomato fruit-specific promoter E8 (GenBank accession No. AF515784.1) and a 402 bp fragment of tomato $r b c S$ gene terminator (GenBank No. X05984.1) were obtained by PCR from the genomic DNA of tomato cv. Yalf with the sets of oligonucleotides E8-prom and 3A-ter, respectively. Amplified PCR products were sequenced by Evrogen (Moscow, Russia) to verify the gene identity and cloned into the modified pUC18. The resulting expression cassette then was placed into the pMF1 vector using AscI and SbfI. DNA cloning was performed according to standard procedures (Maniatis et al., 1982).

\section{Apple Transformation and Marker-Free Plant Production}

Apple plants of a hybrid obtained from free pollination of the Melba variety from Central Genetic Laboratory (Michurinsk, Russia) were used in our experiments. This hybrid has the best characteristics of the parent variety while at the same time having an increased resistance to low temperatures, which is important for the temperate climate conditions.

The plants were cultivated in vitro on $\mathrm{QL}$ medium (Quorin and Lepoivre, 1977) containing 1.5-2.0 $\mathrm{mg} \mathrm{L}^{-1}$ 6benzylaminopurine (BAP) and $0.3 \mathrm{mg} \mathrm{L}^{-1}$ indole-3-butyric acid (IBA), and rooted on half-strength QL medium supplemented with $0.5-1.0 \mathrm{mg} \mathrm{L}^{-1}$ IBA. Leaf pieces from in vitro-rooted plants were used for transformation. Co-cultivation of leaf explants with Agrobacterium tumefaciens strain AGL0 (Hood et al., 1986) carrying plasmid pMF-E8 was performed on MS medium (Murashige and Skoog, 1962) containing $3.0 \mathrm{mg}$ $\mathrm{L}^{-1} \quad \mathrm{~N}$-(2-chloro-4-pyridyl)- $N$-phenylurea (4CPU), $1.0 \mathrm{mg}$ $\mathrm{L}^{-1}$ 1-naphthaleneacetic acid (NAA), and $1 \mathrm{mg} \mathrm{L}^{-1} 2,3,5-$ triiodobenzoic acid (TIBA) for 2-3 days. Regeneration was performed in the dark on the same medium supplemented with $500 \mathrm{mg} \mathrm{L}^{-1}$ cefotaxime and $35 \mathrm{mg} \mathrm{L}^{-1}$ kanamycin. Apple shoots were continuously propagated and rooted on half-strength QL medium with the addition of $0.5 \mathrm{mg} \mathrm{L}^{-1}$ IBA and $25 \mathrm{mg}$ $\mathrm{L}^{-1}$ kanamycin. Analyzed plants of transgenic lines 1 and 6 were subcultured on propagation medium and leaf explants from these shoots were incubated overnight on agarised MS medium supplemented with $10 \mu \mathrm{M}$ Dex and then transferred to propagation medium containing $2 \mu \mathrm{M}$ Dex and $250 \mathrm{mg} \mathrm{L}^{-1} 5$-FC to obtain regenerants again. Putative marker-free plants obtained were then rooted and propagated on shoot propagation medium containing $250 \mathrm{mg} \mathrm{L}^{-1}$ 5-FC and were moved to the greenhouse for further analysis.

\section{Southern Blot Analysis of Putative Marker-Free Plants}

Apple genomic DNA (30 $\mu \mathrm{g})$ was digested overnight at $37^{\circ} \mathrm{C}$ with $60 \mathrm{U}$ HindIII (see position on Figure 1). The fragments were separated on $0.9 \%$ agarose gel and transferred to a positive-charged nylon membrane Hybond $\mathrm{N}+$ (GE Healthcare, Little Chalfont, United Kingdom) by capillary blotting following the manufacturer's instructions. The DNA probes were constructed by PCR using plasmid pMF-E8 as the template. DNA probes of 725 bp (for thaumatin II gene), $440 \mathrm{bp}$ (for nptII gene) or $637 \mathrm{bp}$ (for $\operatorname{Rec} R$ gene) were labeled with alkaline phosphatase using Amersham Gene Images AlkPhos Direct Labelling and Detection System (GE Healthcare). Prehybridization, hybridization (overnight at $62^{\circ} \mathrm{C}$ ) with alkaline phosphatase-labeled probes, and subsequent washings of the membrane were carried out according to the AlkPhos Direct Labeling System protocol. Detection was performed using CDPStar detection reagent following the manufacturer's directions (Amersham CDP-Star Detection reagent, GE Healthcare). The signal from the blot was accumulated on X-ray film (Retina XBE blue sensitive, Carestream Health INC., NY, United States) in film cassette at room temperature for $24 \mathrm{~h}$. X-ray films were scanned on Amersham imager 600 (GE Healthcare Life Sciences, Japan) after development. The same blot was reprobed several times (ThauII, nptII, and RecR). The blot was striped in a $0.5 \%$ $(\mathrm{w} / \mathrm{v}) \mathrm{SDS}$ solution at $60^{\circ} \mathrm{C}$ for $60 \mathrm{~min}$ as described in the protocol for Amersham Gene Images AlkPhos Direct Labelling and Detection System. 
TABLE 1 | Primer sequences and amplicon sizes.

\begin{tabular}{|c|c|c|c|c|}
\hline Acronym & Gene or combination & Forward/reverse primer sequences $\left(5^{\prime}-3^{\prime}\right)$ & $\begin{array}{l}\text { Amplicon } \\
\text { size (bp) }\end{array}$ & Method \\
\hline E8-prom & E8 (promoter) & $\begin{array}{l}\text { CTATCCCGGGAGGCGCGCCAGAAGGAATTCACGAAATC/ } \\
\text { TCAGGATCCCTCПITGCACTGTGAATG }\end{array}$ & 1146 & PCR (cloning) \\
\hline 3A-ter & $\begin{array}{l}\text { Ribulose-1,5- } \\
\text { bisphosphate } \\
\text { carboxylase/oxygenase } \\
(\text { rbcS3A) terminator }\end{array}$ & $\begin{array}{l}\text { ACTGACCGGTTCTAGAAAAACTAATTGCC/ } \\
\text { ACTCCTGCAGGCGAGGGAGTAGTAGAGATAAG }\end{array}$ & 423 & $-»-$ \\
\hline Thau-CDS & Thaumatin II (CDS) & $\begin{array}{l}\text { TAGGATCCATGGCCGCCACCAC/ } \\
\text { ACTACCGGTITACTCGTCTTCAAGTTCAAG }\end{array}$ & 725 & $\begin{array}{l}\text { PCR (cloning), } \\
\text { Southern blotting }\end{array}$ \\
\hline (1) RS site & RS site-35S promoter & CGATTTGATGAAAGAATGAATTAATG/GTGTGTCGTGCTCCACCATG & 526 & PCR \\
\hline (2) $\operatorname{CodA}$ & $\begin{array}{l}\text { CaMV35S promoter- } \\
\text { Cytosine deaminase }\end{array}$ & CCAACCACGTCTTCAAAGCA/AATGCCTTCAAACAGCGTGC & 589 & $-»-$ \\
\hline (3) Nptll & $\begin{array}{l}\text { Neomycin } \\
\text { phosphotransferase II }\end{array}$ & TCTGATGCCGCCGTGTTCC/ATGCGCGCCTTGAGCCTG & 440 & $\begin{array}{l}\text { PCR, RT-PCR, } \\
\text { Southern blotting }\end{array}$ \\
\hline (4) Nos ter & $\begin{array}{l}\text { Nopaline synthase } \\
\text { terminator }\end{array}$ & CCGATCGTTCAAACAT/GTAACATAGATGACACCGCG & 249 & PCR \\
\hline (5) $35 \mathrm{~S}$ prom & CaMV35S promoter & AGCACGACACACTTGTCTACTC/CTCTCCAAATGAAAT & 406 & PCR \\
\hline (6) $\operatorname{Rec} R$ & Recombinase $\mathrm{R}$ & ATGCGCAAGGAGGCAGGTCG/GCCACACGGGAGACGCCTTC & 637 & $\begin{array}{l}\text { PCR, RT-PCR, } \\
\text { Southern blotting }\end{array}$ \\
\hline (7) Thau & Thaumatin ॥ & GCGCTGCCACCTTCGAGATCG/GCAGGTGACGGTGGTTGGCT & 584 & PCR, RT-PCR \\
\hline (8) E8-Thau & $\begin{array}{l}\text { E8 promoter-thaumatin } \\
\text { ॥ }\end{array}$ & CTTAATCAGACGTATTGGGTIC/AGCCTITGATGTTGGAGATGTC & 624 & PCR \\
\hline (9) Thau-ter & $\begin{array}{l}\text { Thaumatin II-rbcS3A } \\
\text { terminator }\end{array}$ & GCTCAACCAGTACGGCAAGG/CAAGGGAAAACCCAAAGGAG & 445 & $-»-$ \\
\hline Actin & Actin 11 & TCATCATACTCGGCCTTCGC/CCATCCATGATTGGAATGGAAGC & 302 & RT-PCR \\
\hline THFS & $\begin{array}{l}\text { Formate- } \\
\text { tetrahydrofolate } \\
\text { ligase }\end{array}$ & AGCAGCGTTGAATACTCAGAG/ATACTGGGTITCGCCATGC & 99 & Real-time PCR \\
\hline TMp1 & $\begin{array}{l}\text { Type } 1 \text { membrane } \\
\text { protein-like }\end{array}$ & AGACCGACTCAATGTTGCTCTC/GTGGAAGGTGGTGCAAATCC & 73 & $-»-$ \\
\hline ACT11 & Actin 11 & GCTGTTCTITCCCTCTACGC/GCATGGGGAAGAGCATATCC & 110 & $-»-$ \\
\hline Th84 & Thaumatin ॥ & AGAGTCCTGGACCATCAAC/CCGCTGTCGTCGAAATAG & 84 & $-»-$ \\
\hline Th113 & $-»-$ & GCACCGTGTTCCAGACGAG/GTCCAGGACATAACTGAACGC & 113 & $-»-$ \\
\hline Th95 & $-»-$ & AGCTCAACTCGGGAGAGTC/GCTGTCGTCGAAATAGCAGTC & 95 & $-»-$ \\
\hline
\end{tabular}

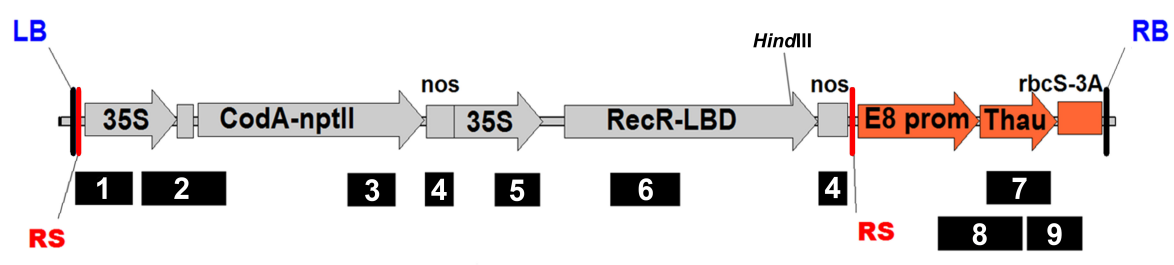

FIGURE 1 | Schematic representation of the pMF-E8 vector T-DNA region with primer set positions. RS, recombination site; RB and LB, right and left border of T-DNA, respectively; 35S, CaMV35S promoter; CodA-nptII, translational fusion gene for positive (nptII) and negative (codA) selection; nos, nopaline synthase terminator; Rec-LBD, translational fusion of Recombinase R-LBD; E8 prom, E8 promoter; Thau, thaumatin II; rbcS3A, rbcS3A terminator. For interpretation of primer set numbers, see Table 1. HindIII, position of the restriction site for which the DNA was digested for the Southern blot assay.

\section{Nucleic Acid Extractions}

The total DNA was isolated from young leaves of in vitro apple plants according to the method described by Rogers and Bendich (1994).

RNA samples were extracted from leaves of in vitro transgenic and control plants using GeneJET Plant RNA Purification Mini Kit (Thermo Fisher Scientific, Waltham, MA, United States). Each sample was treated with DNAse (Thermo).

\section{PCR Experiments}

Primary apple transformants and all selected on medium with 5FC regenerants were studied in detail for the presence of target and selective genes and their regulatory elements by PCR analysis. Nine pairs of primers were used for PCR analysis of the putative marker-free plants (Table 1). Reactions were carried out using HS Taq polymerase (Evrogen) as follows: 1 cycle of $5 \mathrm{~min}$ at $95^{\circ} \mathrm{C}$, followed by 29 cycles of denaturation at $94^{\circ} \mathrm{C}$ for $20 \mathrm{~s}$, 
annealing $20 \mathrm{~s}$, extension at $72^{\circ} \mathrm{C}$ for $40 \mathrm{~s}$, and one final cycle of $3 \mathrm{~min}$ at $72^{\circ} \mathrm{C}$. PCR products were separated using $1.2 \%$ agarose gel electrophoresis, visualized with ethidium bromide under UV light and photographed.

\section{Semiquantitative RT-PCR and Real-Time qPCR}

The cDNA was synthesized using Maxima H Minus Reverse Transcriptase (Thermo) according to the manufacturer's protocol using oligo(dT)18 and random hexameter primers. For each sample, $3 \mu \mathrm{g}$ of total RNA were taken for the reverse transcription reaction in a total volume of $20 \mu \mathrm{l}$ following two-fold dilution. $2 \mu \mathrm{l}$ of cDNA mix was used for PCR reaction. Housekeeping actin (Actin 11) gene as internal control was used for data normalization. PCR was performed using primer sets for recombinase $\mathrm{R}(\operatorname{RecR})$, neomycin phosphotransferase (NptII), and the thaumatin II (Thau) gene (Table 1) as described above. PCR cycles were chosen so that none of analyzed samples reached a plateau at the end of the amplification, that is they were in the exponential phase of amplification. The cDNA samples were checked for genomic DNA contamination by using controls without reverse transcriptase. The PCR products were separated in a $1.2 \%$ agarose gel, photographed and analyzed with the program GelQuant.NET ${ }^{1}$ for semi-quantitative estimation.

To quantify the RNA levels of the thaumatin II gene by quantitative real-time PCR, the cDNA of the control and transgenic apple plants obtained as described above were used. Three reference housekeeping genes were tested as endogenous control: THFS, TMp1, and ACT11 (Perini et al., 2014; Table 1). We also designed three sets of primers for the target sequence of the thaumatin II gene (Table 1). For each set of primers the optimum annealing temperature was found using temperature gradients. We tested amplification efficiency using a series of 10fold dilutions in triplicate. These values were used to calculate the standard curves and slopes and to compare the PCR efficiency. The experiments were performed on a LightCycler 96 instrument (Roche Diagnostics GmbH, Mannheim, Germany) using the PowerUp SYBR Green Master Mix reagent (Thermo) in plates (Axygen Biosciences, Union City, NJ, United States) in a volume of $20 \mu \mathrm{l}$. The PCR reaction conditions and the melting analysis of the products were selected according to the manufacturer's recommendations. The $2^{-\Delta \Delta C T}$ method (Livak and Schmittgen, 2001) was used to normalize and calibrate the ThauII values relative to the endogenous controls. Every sample was analyzed in triplicate. Data calculation and statistical analysis were performed using both the software supplied with the Roche device and Microsoft Excel. Primer sequences and amplicon sizes are given in Table $\mathbf{1}$.

\section{RESULTS}

\section{Construction of the Binary Vector}

For obtaining the marker-free transgenic apple plants we used the vector pMF (Plant Research International, Wageningen)

${ }^{1}$ http://biochemlabsolutions.com containing recombinase $\mathrm{R}$ from the yeast $Z$. rouxii fused to the LBD of the glucocorticoid receptor and the bifunctional selection gene CodA-nptII, allowing the selection of plants by negative selection on 5-FC after removal of the undesirable region of DNA from the genome. We have used the thaumatin II protein gene from the tropical plant Thaumatococcus daniellii cloned by Edens et al. (1982) as the sense gene under the control of tomato E8 gene fruit-specific promoter and tomato $r b c S$ gene terminator. This protein has a supersweet flavor and exhibits antifungal activity, thus the expression of the gene allows improving the taste quality of fruits and increasing the resistance to phytopathogens. The resulting vector was named pMF-E8 (Figure 1).

\section{Apple Transformation and PCR Analysis of Plants}

We carried out two transformation experiments in which 160 and 85 leaf explants were taken, respectively. Three kanamycinresistant lines (two and one, respectively) were obtained as a result of Agrobacterium-mediated transformation of apple by using pMF-E8 vector. Transformation frequency was $1.2 \%$. These plants were thoroughly tested by PCR for the presence of all genes from the T-DNA region and for the presence of both RS, which is a necessary condition for correct DNA excision. Results of the PCR analysis are shown in Table 2.

Insertion of the target thaumatin gene, as well as other genes of the transferred region, was detected in all three lines, whereas the presence of the recombination site, which is located closer to the left border of T-DNA, occurred only in line 6 .

\section{Obtaining Marker-Free Apple Plants}

The strategy of delayed selection was used to create marker-free apple plants. This strategy involves obtaining transgenic plants and their subsequent manipulation to remove the marker gene.

The following variants are presented in Table 3 were designed for experiments on obtaining the marker-free lines through the induction of recombinase and the subsequent cultivation of explants on the medium with dexamethasone.

By using PCR it was found that the entire sequence of the T-DNA with the site of recombination at the left border is present only in line 6. The presence of both RS flanking the selective genes in the T-DNA region is a prerequisite for successful DNA removal. Nevertheless, we arbitrarily chose one of the remaining lines (line 1) for the first experiment as a negative control and line 2 was excluded. Two experiments were carried out; in the second experiment only the explants of line 6 were used, and variant 0-2 with delayed selection was excluded. From a total of 1800 apple leaf explants 45 regenerants were selected and propagated on the selective medium in the presence of $250 \mathrm{mg} \mathrm{L}^{-1} 5$-FC. As

TABLE 2 | Analysis of transgenic apple plants.

\begin{tabular}{lccccccc} 
Line & RS site & CodA & NptII & RecR & 35S prom. & Thau-CDS & Thau-ter \\
\hline 1 & - & + & + & + & + & + & + \\
2 & - & + & + & + & + & + & + \\
6 & + & + & + & + & + & + & +
\end{tabular}


a result of these experiments, five regenerants were obtained from explants of line 1 and 40 from explants of line 6 (Figures $2 \mathbf{a}-\mathbf{c}$ and Table 4). Spontaneous recombination and DNA excision without treatment with Dex occured - four sublines were derived from explants of line 6 .

The strategy of immediate selection (250-2) was somewhat more effective compared to the delay for 7 days (0-2). The efficiency for line 6 was $8 \%$ for the first experiment and $16.2 \%$ in the second experiment and for the delayed selection the efficiency was $5.6 \%$. Line 1 had an efficiency of $1 \%$ with the delayed and $2.6 \%$ with the immediate selection, suggesting either escapes or a low level of spontaneous deletions as line 1 did not have both recombinase sites. To test the negative effects of the selection and induction on regeneration, non-transformed controls were tested resulting in 55.5\% regeneration on the selection and induction to $75 \%$ with no selection or induction in the first experiment and $27 \%$ relative to $45.2 \%$ in the second experiment.

\section{PCR and Southern Blot Analysis of Marker-Free Plants}

PCR analysis revealed that all five sublines obtained from explants of line 1 are escapes, because in addition to the thauII gene they contain sequences of $n p t I I, \operatorname{CodA}$, and RecR genes. There is no positive signal for selective genes in the PCR with genomic DNA of all sublines derived from line 6 , while the gene of interest with its regulatory sequences is present in all forty sublines, which

TABLE 3 | Marker-free apple obtaining experimental options.

\begin{tabular}{cccc}
\hline Code Name & Induction, & Selection, & Selection, Intent \\
$10 \mu \mathrm{M}$ & $250 \mathrm{mg} \mathrm{L}^{-1}$ & $250 \mathrm{mg} \mathrm{L}^{-1}$ \\
Dex & $5-\mathrm{FC}$ & $5-\mathrm{FC}$ \\
& (immediate) & (delayed for \\
& & 7 days)
\end{tabular}

\begin{tabular}{|c|c|c|c|c|c|}
\hline $0-0$ & $\begin{array}{l}\text { Without } \\
\text { selection }\end{array}$ & - & - & - & $\begin{array}{l}\text { Background } \\
\text { regeneration }\end{array}$ \\
\hline $0-2$ & $\begin{array}{l}\text { Delayed } \\
\text { selection }\end{array}$ & + & - & + & $\begin{array}{l}\text { DNA excision, } \\
\text { selection begins } \\
\text { after } 7 \text { days }\end{array}$ \\
\hline $250-0$ & $\begin{array}{l}\text { Without } \\
\text { induction }\end{array}$ & - & + & + & $\begin{array}{l}\text { Background DNA } \\
\text { excision }\end{array}$ \\
\hline $250-2$ & $\begin{array}{l}\text { Immediate } \\
\text { selection }\end{array}$ & + & + & + & $\begin{array}{l}\text { DNA excision; } \\
\text { impact of } 5-F C \\
\text { and Dex on } \\
\text { regeneration }\end{array}$ \\
\hline
\end{tabular}

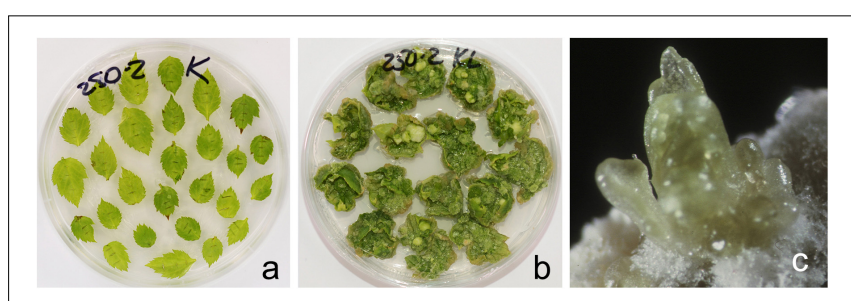

FIGURE 2 | Obtaining marker-free apple plants. (a) Leaf explants of primary transgenic line 6. (b) Regeneration on medium supplemented with 5-FC. (c) Developing young shoot. indicates more or less correct excision of both fusions of selective genes. The Figure 3 represents PCR analysis of 9 sublines derived from line 6 and 3 sublines derived from line 1 (reaction to the RecR gene is not shown). To confirm the results obtained by PCR, we performed Southern blot hybridization using genomic DNA of three primary and two potential marker-free sublines (Figure 4). It was found that the genomes of lines 1, 2, and 6 contain 5,2 , and 3 copies of the target gene, respectively, and one copy of each of the selective genes. Apparently there had been a partial integration of T-DNA region with the target gene only. After recombinase activation, probes for the RecR and $n p t I I$ genes do not hybridize in both analyzed sublines, but two bands are detected for the thaumatin gene.

\section{Analysis of the Selective and Target Genes Expression by RT-PCR}

To estimate the transcription level of the target gene in markerfree apple plants we used semi-quantitative reverse transcription PCR. For this, the total RNA was isolated from young sterile plants, and then used as a matrix for reverse transcription. In the first experiment, in addition to the target gene, we analyzed the expression of selective genes of neomycin phosphotransferase $(n p t I I)$ and recombinase $(\operatorname{Rec} R)$ in the parental transgenic plants and some of the obtained sublines. The results of the analysis are shown in Figure 5. As confirmation of the alignment of produced cDNA, the product of the "housekeeping" gene actin was used. Expression of all genes from T-DNA was detected in three parental lines. In the mRNA of sublines derived from line 6 only the thaumatin II gene remained after excising undesired DNA. In subline 1-1, obtained from line 1, mRNA of selective genes was also detected. Previously, using PCR and Southern blotting, it was found that the plant of this subline is an escape that has passed through the stage of negative selection.

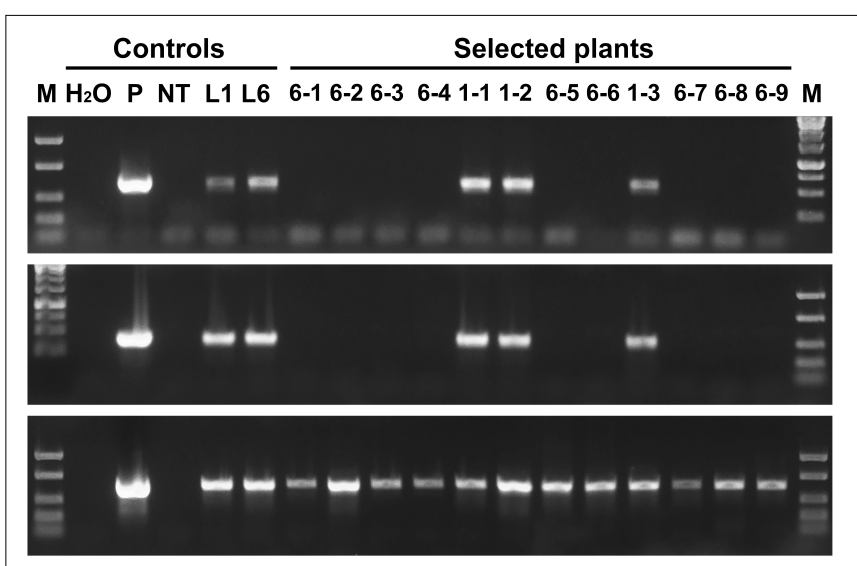

FIGURE 3 | Molecular analysis of apple plants after recombinase induction. Polymerase chain reaction analysis using specific primers for codA (upper panel), nptll (middle panel) and thaull (bottom panel). M, molecular weight marker; $\mathrm{H}_{2} \mathrm{O}$, water; P, plasmid pMF-E8; NT, non-transgenic plant; L1 and L6, primary transgenic lines; other numbers, obtained sublines, the first number indicates from which line the plant was derived. 
TABLE 4 | Selection of putative marker-free regenerants.

\begin{tabular}{|c|c|c|c|c|c|c|c|c|}
\hline \multirow[t]{2}{*}{ Event } & \multirow[t]{2}{*}{ Variant } & \multirow[t]{2}{*}{ Line } & \multicolumn{2}{|c|}{ Number of explants } & \multicolumn{2}{|c|}{ Number of regenerants } & \multicolumn{2}{|c|}{ Regeneration efficiency, \% } \\
\hline & & & Initially ${ }^{1}$ & Before regeneration ${ }^{2}$ & Cut $^{3}$ & Rooted $^{4}$ & Primary 5 & Final $^{6}$ \\
\hline \multirow[t]{8}{*}{ I } & $0-2$ & 1 & 127 & 101 & 8 & 1 & 7.9 & 1 \\
\hline & & 6 & 226 & 198 & 35 & 11 & 17.7 & 5.6 \\
\hline & $250-0$ & 1 & 159 & 159 & 2 & 0 & 1.3 & 0 \\
\hline & & 6 & 161 & 161 & 32 & 2 & 19.9 & 1.2 \\
\hline & $250-2$ & 1 & 155 & 152 & 27 & 4 & 17.8 & 2.6 \\
\hline & & 6 & 180 & 162 & 48 & 13 & 29.6 & 8 \\
\hline & $0-0$ & NT & 159 & 104 & 78 & - & 75 & - \\
\hline & $250-2$ & & 142 & 119 & 66 & - & 55.5 & - \\
\hline \multirow[t]{4}{*}{$\|$} & $250-0$ & 6 & 253 & 53 & 12 & 2 & 22.6 & 3.8 \\
\hline & $250-2$ & & 98 & 74 & 17 & 12 & 23.0 & 16.2 \\
\hline & $0-0$ & NT & 66 & 31 & 14 & - & 45.2 & - \\
\hline & $250-2$ & & 75 & 37 & 10 & - & 27.0 & - \\
\hline \multicolumn{5}{|c|}{ Total number of obtained regenerants } & & 45 & & \\
\hline
\end{tabular}

${ }^{1}$ total number of cut explants; ${ }^{2}$ remaining number of explants after two passages; ${ }^{3}$ number of shoots separated from the explant for rooting; ${ }^{4}$ number of rooted shoots; ${ }^{5}$ ratio of cut shoots to the total number of explants before regeneration; ${ }^{6}$ ratio of rooted shoots to the total number of explants before regeneration.

Further, using semi-quantitative RT-PCR analysis, we estimated the relative level of expression of the thaumatin II gene in all the resulting marker-free apple plants (Figure 6). The actin gene shows that the amount of cDNA taken for the reaction is the same in all analyzed samples. The difference in signal level of the target gene indicates individual characteristics of the apple sublines. Despite the presence of a target gene sequence in all apple plants, the expression of the thaumatin II gene in these experimental conditions could not be detected in two sublines and in another six sublines it was very weak. Using the GelQuant program, the relative level of expression was compared among all the resulting marker-free sublines and eight selected super-expressing plants were identified.

\section{Analysis of the Target Gene Expression by Real-Time PCR}

Before the experiments on the evaluation of the level of expression of the transferred thaumatin II gene in apple plants, it was necessary to determine whether the selected primers are suitable for real-time PCR quantification and their specificity, and also to determine the optimum annealing temperatures for each pair. For this, PCR reactions were carried out with an annealing temperature gradient from $58^{\circ} \mathrm{C}$ to $68^{\circ} \mathrm{C}$, followed by analysis of the melting curves of the reaction products. This method makes it possible to determine whether non-specific products are present in the mixture. Since our experiments use an intercalating dye that binds to any double-stranded DNA, the specificity of the reaction is of fundamental importance for the correct evaluation of the results. Only a single peak was found for all pair primers, indicating the homogeneity of the amplicon and the high specificity of the reaction. The optimum annealing temperatures were: ACT11 $-62^{\circ} \mathrm{C}$, THFS $65^{\circ} \mathrm{C}$, TMp $1-65^{\circ} \mathrm{C}$, Th84 - 62 ${ }^{\circ} \mathrm{C}$, Th113 - $65^{\circ} \mathrm{C}$, Th95 $62^{\circ} \mathrm{C}$. The efficiency of the reaction is also an important parameter when optimizing the reaction conditions. Under ideal conditions, it is 2 . In our experiments, the efficiency of reactions for primers of "housekeeping" genes varied from 1.9 to 1.95 , and for primers of the thaumatin II gene, from 1.79 to 1.9 , with the best result for Th84. In some cases, the features of the primary structure of the DNA of the studied gene, as well as the high degree of nucleotide homology with other genes, do not allow to design primers providing ideal conditions for the reaction run. Since all the selected primers were suitable for real-time PCR analysis, we used the Th84 set for the target gene and all three pairs for the "housekeeping" genes. The geometric mean of the three selected housekeeping genes was validated as an accurate normalization factor (Vandesompele et al., 2002). The level of expression of the thaumatin gene in parental line 6 was taken as 1.

Expression of the thaumatin II gene was detected in all of the marker-free sublines except subline 35 (Figure 7). The highest content of thaumatin mRNA, in transgenic apple subline 10, was three-fold higher than in the parental line. In eight apple sublines, the level of expression was statistically higher than in line 6 and in two of them it was twice as high. In nine lines, the expression of the target gene was approximately the same. In subline 35 , it was not possible to detect the mRNA of the target gene. In the remaining 11 sublines, thaumatin expression was lower than in line 6 . The method of quantitative evaluation of the expression of the thaumatin gene largely confirmed the results obtained with semi-quantitative RT-PCR. So, plants with a weak signal level in real-time PCR also showed extremely low values, and lines with a high signal in RTPCR performed best in the real-time PCR analysis. Only for subline 25 the results of the two methods of analysis turned out to be different - using semi-quantitative RT-PCR failed to detect the high level of expression revealed by the realtime PCR method. 


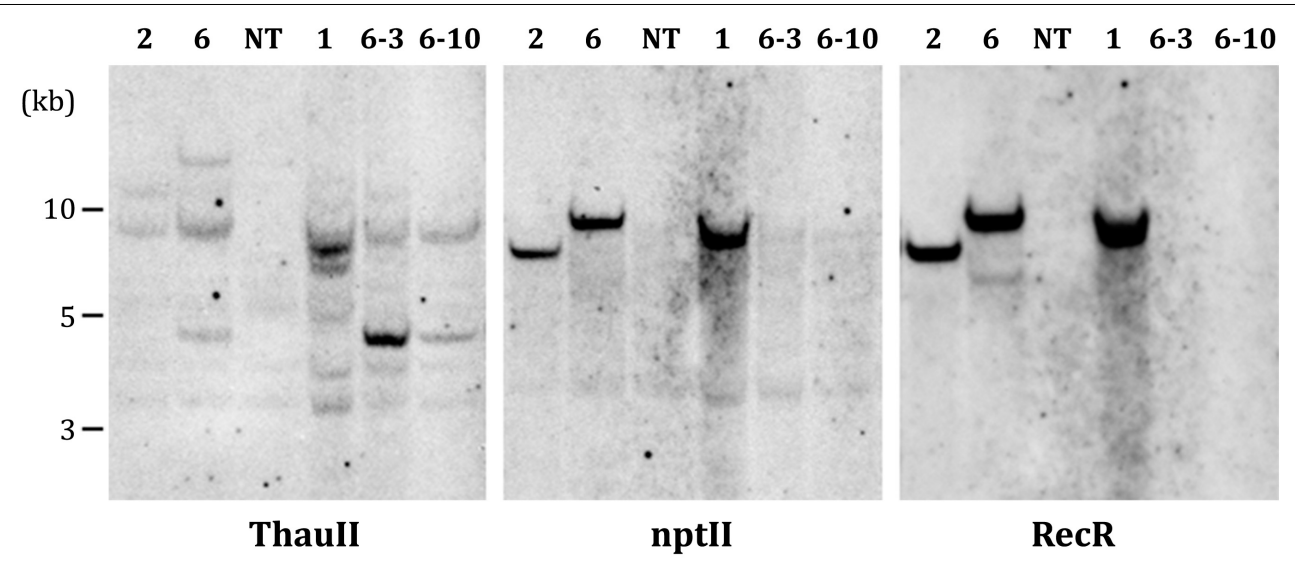

FIGURE 4 | Southern blot analysis of parental (1, 2, and 6) and marker-free (6-3, 6-10) apple plants. NT, non-transgenic control.

To assess the level of expression of the thaumatin II gene in marker-free plants, both methods proved to be suitable and demonstrated similar results. Semi-quantitative reverse transcription PCR allows, first of all, to exclude plants without expression, or at very low values, whereas the realtime PCR method allows a more accurate estimate to be obtained - in this case it is possible to obtain data on how much the mRNA level of the analyzed gene in a particular plant is changed with respect to other sublines and primary transgenic lines.

As a result of the analyses, we selected eight superexpressing sublines, in which the mRNA level of the thaumatin II gene exceeded the value for the parental line 6 1.5-3 times. Plants with the highest level propagated and grafted onto dwarf rootstocks for early fruit production. Our plan is to estimate the quantitative thauII expression of profiling in fruits next and to measure the level of protein.

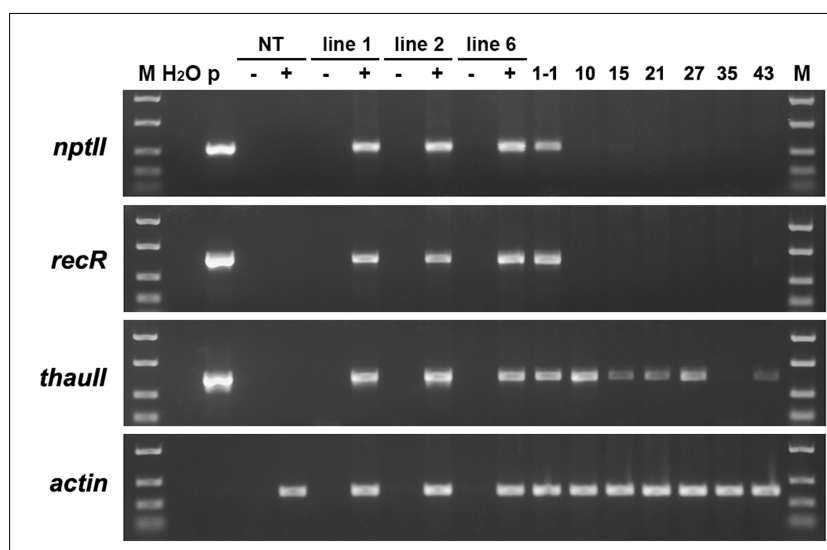

FIGURE 5 | Semiquantitative RT-PCR analysis of four genes in apple plants. $\mathrm{M}$, molecular weight marker; $\mathrm{H}_{2} \mathrm{O}$, water; $\mathrm{p}$, plasmid pMF-E8; NT, non-transgenic control; lines 1, 2, and 6, parent transgenic lines; other numbers, some of the produced sublines; -, reaction performed without the addition of reverse transcriptase; +, reaction performed with RT.

\section{DISCUSSION}

Sweetness is a major factor in consumer preferences, and therefore, increasing sweetness is an important topic in apple breeding programs. In addition to this, research continues on the composition of apple fruits, and the effects of various metabolites on taste and sweetness (Ma et al., 2015; Aprea et al., 2017). Instead of the classical selection with its search for new wild forms with sweet fruits, a more promising approach we see is the heterologous expression of supersweet proteins in apple fruits. We have successfully worked to improve the taste of the fruits of different fruit crops, including woody plants (Dolgov et al., 2011). In the present work, we applied marker-free technologies simultaneously using only genes of plant origin to produce apple trees expressing supersweet protein. The strategy of delayed selection was used to create markerfree apple plants. This strategy involves obtaining transgenic plants and their subsequent manipulation to remove the marker gene. The working concentration of dexamethasone as recombinase activator was $10 \mu \mathrm{M}$ in accordance with the recommendations by the system designer; evidence that the maximum induction effect is observed at Dex concentrations of $10 \mu \mathrm{M}$ is also available (Aoyama and Chua, 1997). Vanblaere et al. (2011) use the same concentration to activate the recombinase, whereas in later work, the creators of the pMF system unexpectedly raise the concentration to $50 \mu \mathrm{M}$ (Krens et al., 2015) which we have not compared but we achieved a higher \% of rooted plants following induction with $10 \mu \mathrm{M}$. In another study, increasing the concentration of Dex from 10 to $50 \mu \mathrm{M}$ did not reliably enhance (except one apple line) recombinant activity in apple and pear (Righetti et al., 2014).

In our experiments the concentration of 5-fluorocytosine was $250 \mathrm{mg} \mathrm{L}^{-1}$, which did not provide a very strong selective pressure. In most works with plants $150-300 \mathrm{mg} \mathrm{L}^{-1}$ is used (Schaart et al., 2004; Vanblaere et al., 2011; Righetti et al., 2014). Replacement of the liquid medium by a solid one at the step of cultivation with dexamethasone positively affects the viability of explants without losing efficiency (unpublished data). 


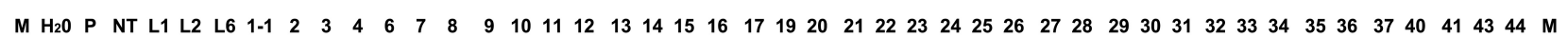

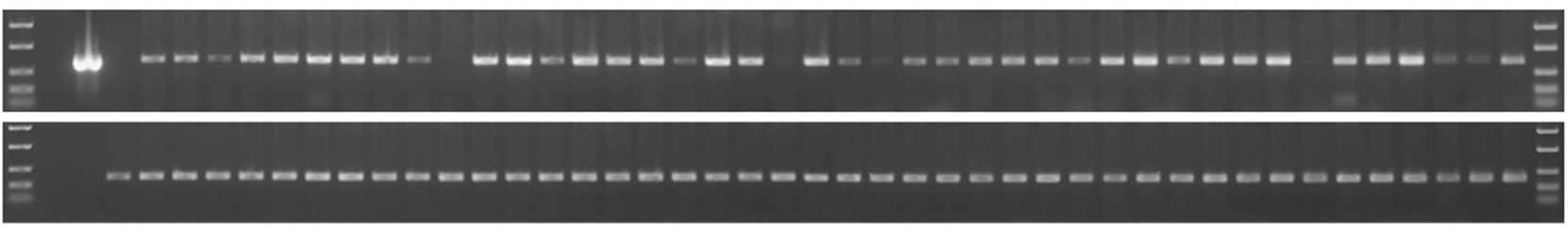

FIGURE 6 | Semiquantitative RT-PCR analysis of thaumatin II gene expression in marker-free apple plants. In the upper panel the thaumatin gene is shown, in the lower panel the housekeeping actin gene. $\mathrm{M}$, molecular weight marker; $\mathrm{H}_{2} \mathrm{O}$, water; $\mathrm{p}$, plasmid pMF-E8 (used for plant transformation); NT, non-transgenic control; L1, L2, and L6, parent transgenic lines; other numbers, marker-free sublines (except 1-1).

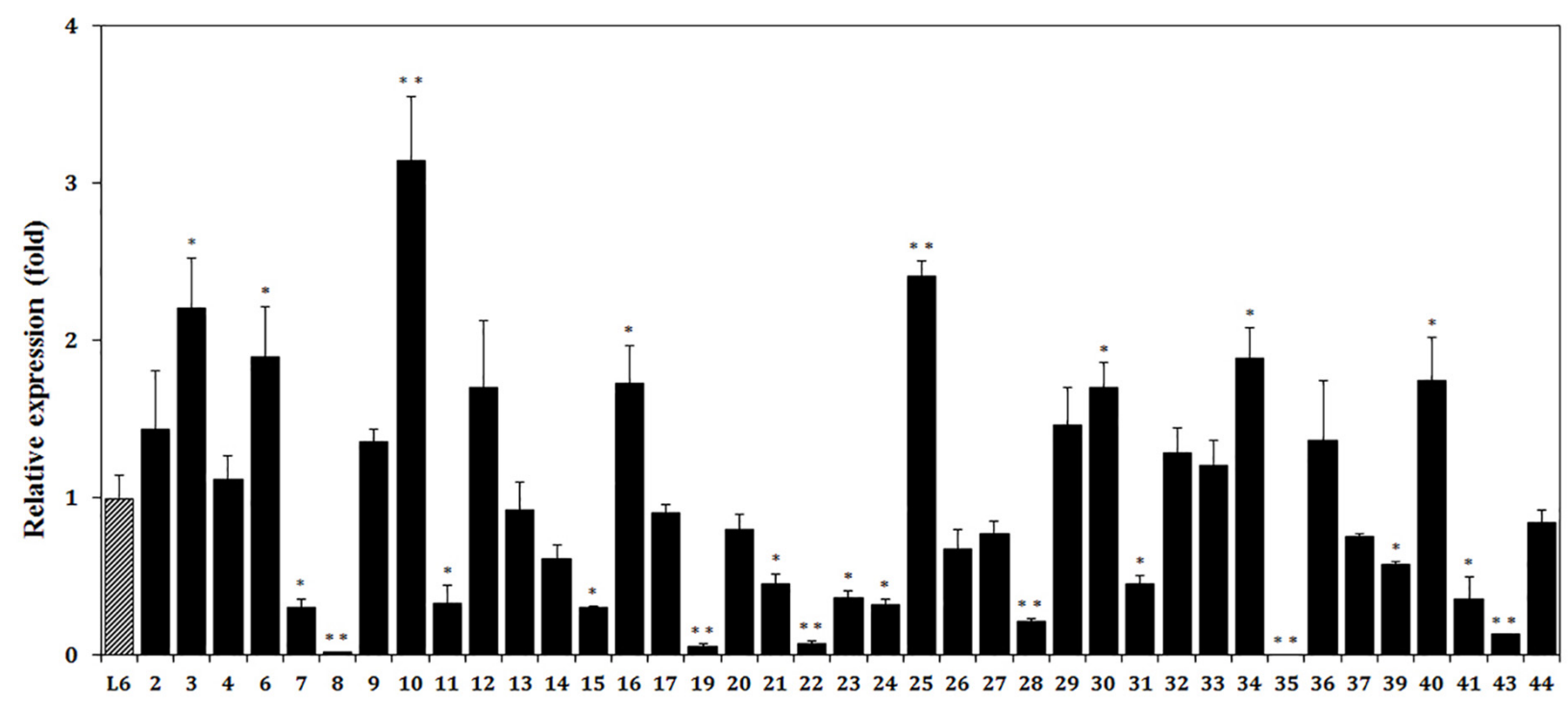

Sublines

FIGURE 7 | Relative expression levels of thaumatin II gene in different marker-free apple sublines. The data were normalized by combination of all reference genes. Thus, 1 is the value of parental transgenic line 6 (L6). The presented values are means of three replicates and the bars are standard deviations. ${ }^{*} p<0.05$ and $* * p<0.01$ - significant differences by Student's $t$-test.

We have obtained marker-free apple plants using a bifunctional selectable gene and inducible site-specific recombinase R. PCR analysis revealed that all selected plants from line 6 were free of selectable markers. The delayed selection procedure (0-2 variant) produced 11 marker-free plants and instant selection produced 13 (250-2 variant) in a first experiment. Very often delayed selection in cases with Agrobacterium-mediated transformation allows increasing the efficiency of regeneration, but in case of selection on 5-FC a positive effect was not observed. These similar results show that both variants are equally suitable for an effective protocol and this correlates with work in which instant selection was successfully applied to produce marker-free apple plants (Vanblaere et al., 2011; Krens et al., 2015).

Based on results obtained using Southern blotting it can be assumed that in the genome of primary transgenic line 6 there is one full copy of T-DNA and two additional inserts only with the target gene expression cassette, which remain after DNA excision. A possible tandem insertion of two copies of the target genes and a third copy into another part of the genome resulted in the loss of one of the cassettes after recombination. Additional detailed molecular investigations of the structure of inserts in marker-free plants will reliably confirm this assumption and characterize the integration and excision events. Previously, a complete molecular analysis of apple cisgenic plants carrying the scab resistance gene Rvi6 (2013) was carried out. Various

TABLE 5 | Analyzed apple sublines.

\begin{tabular}{lcccc}
\hline $\begin{array}{l}\text { Parental } \\
\text { transgenic } \\
\text { line }\end{array}$ & $\begin{array}{c}\text { Total number } \\
\text { of obtained } \\
\text { sublines }\end{array}$ & $\begin{array}{c}\text { Sublines } \\
\text { expressing } \\
\text { nptll/codA } \\
\text { gene }\end{array}$ & $\begin{array}{c}\text { Marker-free } \\
\text { sublines }\end{array}$ & $\begin{array}{c}\text { Sublines } \\
\text { expressing } \\
\text { thaull gene }\end{array}$ \\
\hline 1 & 5 & 5 & 0 & 5 \\
6 & 40 & 0 & 40 & 39
\end{tabular}


combinations of multiple T-DNA inserts and the emergence of possible genotypes from a single transgenic line have been shown (Vanblaere et al., 2013). Ideally, when working with vector systems based on site-specific recombinases, one should strive to obtain transgenic plants with one whole copy of T-DNA by optimizing transformation strategies. Otherwise, in addition to the known disadvantages of multiple inserts during recombination, the likelihood of unwanted chromosomal rearrangement appears or makes DNA elimination impossible (see review Wang et al., 2011). It is thought that chromosome rearrangement or deletion one of the main negative impacts of site-specific recombinase-based systems (Yau and Stewart, 2013).

The architecture of the T-DNA copy, namely the lack of one of the RS in the genome of line 1, does not allow deleting the undesirable DNA by the prevention of sitespecific recombination. We obtained five plants after the incubation of explants from line 1 (which did not contain one of the RS sites) on 5-FC, indicating that selection was insufficient. At the same time the lack (absence) of line 6 escapes leads to the conclusion that the chosen concentration of 5 -FC $\left(250 \mathrm{mg} \mathrm{L}^{-1}\right)$ is quite adequate for routine markerfree apple plant selection. Interestingly, in early work one team of authors used a concentration of $150 \mathrm{mg} \mathrm{L} \mathrm{L}^{-1}$ (Vanblaere et al., 2011) for marker-free apple production, but in later work the concentration was increased to $500 \mathrm{mg} \mathrm{L}^{-1}$ (Krens et al., 2015).

The regeneration frequency of non-transgenic plants on medium without 5-FC and Dex was $75 \%$ in the first experiment and $45 \%$ in the second experiment. Concentrations of 5-FC ranging from 50 to $500 \mathrm{mg} \mathrm{L}^{-1}$ have been shown to be effective for negative selection at the regeneration stage (Schlaman and Hooykaas, 1997) without negative effect up to $1000 \mathrm{mg} \mathrm{L}^{-1}$ (Dai et al., 2001). Righetti et al. (2014) reported that toxicity of 5-FC measured during adventitious bud regeneration was not detectable in apple below a dose of $750 \mathrm{mg} / \mathrm{l}$. In our hands the presence of Dex and 5-FC in the medium adversely affects non-transgenic tissue regeneration, reducing the frequency by about 1.5 times - decreasing the regeneration frequency to 55 and $27 \%$, respectively.

Spontaneous recombination and DNA excision occurs on average in $14 \%$ of the cases (comparing variants $250-0$ and 250 2 ) in experiments with apple tissues - in four sublines derived from explants of line 6 . The observation that recombination had already taken place without treatment with Dex suggests that non-induced gene expression occurs. A similar result was obtained by Schaart et al. (2004) with strawberry plants. High level of spontaneous recombination was previously demonstrated in apple and pear: $19-34 \%$ of the transgenic lines presented partial recombination in absence of Dex induction (Righetti et al., 2014). In our work, we used one of the well-characterized fruit-specific promoters of the tomato $\mathrm{E} 8$ gene to drive the expression of the thaumatin II protein gene. Although the expression of the E8 gene is controlled in both an ethylenedependent and an ethylene-independent manner (Lincoln et al., 1987; Lincoln and Fischer, 1988; Dellapenna et al., 1989;
Theologis et al., 1993) we did not find any reports regarding the expression of the E8 gene in vegetative tissues of plants. Moreover, none of the deleted forms of the promoter, not even containing an ethylene-responsive element located between -2181 and -1088 , ensured the accumulation of the E8-Tag gene product in unripe fruits (Deikman et al., 1992). In another work $1.1 \mathrm{~kb}$ E8 gene promoter provided expression of S-adenosylmethionine hydrolase at three stages of fruit development (breaker, orange and ripe) whereas immature and mature leaves, flowers and stems, were negative for the presence of SAMase RNA (Good et al., 1994). Interestingly, that Kurokawa et al. (2013) mention in the title of their work that "...E8 promoter-HSP terminator cassette promotes the highlevel accumulation of recombinant protein predominantly in transgenic tomato fruits...," is apparently due to the fact that low accumulation of miraculin was detected in the green fruits. It was concluded that heat shock terminator is a strong expression enhancer that can disrupt the tissue-specificity of expression of E8 gene promoter (Kurokawa et al., 2013). However, it was previously shown that a $2181 \mathrm{bp}$ version, in contrast to the deleted ones, drives the accumulation of E8 in the unripe fruits of tomato (Deikman et al., 1992). Studies on the molecular evolution of the E8 gene promoter of tomato and the search for differences between functional regions in Solanum species may allow answering emerging questions (Zhao et al., 2009). In our hands, even in tomato plants, gene expression is observed under the control of the $1193 \mathrm{bp}$ promoter in vegetative tissues (Timerbaev et al., 2014). Expression levels in leaves and fruits vary considerably, but correlate with each other by result of Western blotting analysis. Quantification by ELISA showed that the protein levels of thaumatin in fruits on average 4fold higher than the leaves (unpublished data). Due to this, it became possible to estimate the transcription level of the target gene in leaves of marker-free apple plants using semiquantitative reverse transcription PCR and real-time PCR. We expect to obtain higher levels of expression of the thauII gene in apple fruits as E8 is predominantly expressed in green and ripe fruits than in leaves.

The results of apple plant selection and the analysis of T-DNA gene expression are summarized in Table 5 . Altogether, 45 sublines were obtained; five of them were escapes, 40 were fully marker-free. Using real-time PCR, expression was shown in 39 marker-free plants, eight of which were selected for the rapid production of fruits and further analyses. Grafted onto dwarf rootstocks, after fruit production marker-free apple plants will be checked for taste improvement and used for future selection. So, using a vector based on the pMF system we developed an acceptable protocol for the production of marker-free apple plants - a high efficiency of excision of undesirable DNA from the apple genome was demonstrated - obtained from only one parental transgenic line. Our studies show how the scope for further improving the traits of traditional apple cultivars can be widened using markerfree technologies. The germplasm of apple tree can be expanded by genetic engineering without using genes from other taxa. 


\section{DATA AVAILABILITY}

The datasets generated for this study are available on request to the corresponding author.

\section{AUTHOR CONTRIBUTIONS}

VT constructed the transformation vector, obtained marker-free apple plants, carried out PCR and qRT-PCR, and wrote the

\section{REFERENCES}

Aoyama, T., and Chua, N. H. (1997). A glucocorticoid-mediated transcriptional induction system in transgenic plants. Plant J. 11, 605-612. doi: 10.1046/j.1365313X.1997.11030605.x

Aprea, E., Charles, M., Endrizzi, I., Corollaro, M. L., Betta, E., Biasioli, F., et al. (2017). Sweet taste in apple: the role of sorbitol, individual sugars, organic acids and volatile compounds. Sci. Rep. 7:44950. doi: 10.1038/srep 44950

Dai, S., Carcamo, R., Zhang, Z., Chen, S., and Beachy, R. N. (2001). The bacterial cytosine deaminase gene used as a conditional negative selection marker in transgenic rice plants. Plant Cell Rep. 20, 738-743. doi: 10.1007/s002990100390

Dale, E. C., and Ow, D. W. (1991). Gene transfer with subsequent removal of the selection gene from the host genome. Proc. Natl. Acad. Sci. U.S.A. 88, 10558-10562. doi: 10.1073/pnas.88.23.10558

Daley, M., Knauf, V. C., Summerfelt, K. R., and Turner, J. C. (1998). Cotransformation with one Agrobacterium tumefaciens strain containing two binary plasmids as a method for Marker-free transgenics producing markerfree transgenic plants. Plant Cell Rep. 19, 489-496. doi: 10.1007/s0029900 50430

Deikman, J., Kline, R., and Fischer, R. L. (1992). Organization of ripening and ethylene regulatory regions in a fruit-specific promoter from tomato (Lycopersicon esculentum). Plant Physiol. 100, 2013-2017. doi: 10.1104/pp.100. 4.2013

Dellapenna, D., Lincoln, J. E., Fischer, R. L., and Bennett, A. B. (1989) Transcriptional analysis of polygalacturonase and other ripening associated genes in rutgers, rin, nor, and $\mathrm{Nr}$ tomato fruit. Plant Physiol. 90, 1372-1377. doi: 10.1104/pp.90.4.1372

Dolgov, S. V., Lebedev, V. G., and Firsov, F. P. (2011). Pear fruit taste modification by thaumatin II gene expression. Acta Hortic. 909, 67-73. doi: 10.17660/ ActaHortic.2011.909.5

Ebinuma, H., and Komamine, A. (2001). MAT (multi-auto-transformation) vector system. The oncogenes of Agrobacterium as positive markers for regeneration and selection of marker-free transgenic plants. In Vitro Cell. Dev. Biol. Plant 37, 103-113. doi: 10.1007/s11627-001-0021-2

Ebinuma, H., Sugita, K., Matsunaga, E., and Yamakado, M. (1997). Selection of markerfree transgenic plants using the isopentenyl transferase gene as a selectable marker. Proc. Natl. Acad. Sci. U.S.A. 94, 2117-2121. doi: 10.1073/ pnas.94.6.2117

Edens, L., Heslinga, L., Klok, R., Ledeboer, A. M., Maat, J., Toonen, M. Y., et al. (1982). Cloning of cDNA encoding the sweet-tasting plant protein thaumatin and its expression in Escherichia coli. Gene 18, 1-12. doi: 10.1016/0378-1119(82) 90050-6

Firsov, A., Pushin, A., and Dolgov, S. (2018). "Transgenic plants as producers of supersweet protein thaumatin II," in Sweeteners. Reference Series in Phytochemistry, eds J. M. Mérillon and K. Ramawat (Cham: Springer).

Gaskell, G., Stares, S., Allansdottir, A., Allum, N., Corchero, C., Fischler, C., et al. (2013). Europeans and Biotechnology in 2010: Winds of Change? - A report to the European Commission's Directorate-General for Research. Brussels: European Commission.

Gleave, A. P., Mitra, D. S., Mudge, S., and Morris, B. A. (1999). Selectable markerfree transgenic plants without sexual crossing: transient expression of Cre recombinase and use of the conditional lethal dominant gene. Plant Mol. Biol. 40, 223-235. doi: 10.1023/A:1006184221051 manuscript. TM obtained the transgenic apple plants. AP did the Southern blot analysis. SD acted as scientific adviser of this project and performed of plant grafting.

\section{FUNDING}

This research was supported by Russian Science Foundation Grant No. 14-50-00079. This work was carried out using the unique scientific installation "Fitotron" (Registration No. 2-2.9).

Goldsbrough, A. P., Lastrella, C. N., and Yoder, J. I. (1993). Transposition-mediated re-positioning and subsequent elimination of marker genes from transgenic tomatoes. Biotechnology. 11, 1286-1292. doi: 10.1038/nbt1193-1286

Good, X., Kellogg, A. J., Wagoner, W., Langhoff, D., Matsumura, W., and Bestwick, R. (1994). Reduced ethylene synthesis by transgenic tomatoes expressing S-adenosylmethionine hydrolase. Plant Mol. Biol. 26, 781-790. doi: 10.1007/BF00028848

Haverkort, A. J., Boonekamp, P., Hutten, R., Jacobsen, E., Lotz, B., Kessel, G., et al. (2016). Durable late blight resistance in potato through dynamic varieties obtained by cisgenesis: scientific and societal advances in the DuRPh project. Potato Res.. 59, 35-66. doi: 10.1007/s11540-015-9312-6

Hood, E. E., Helmer, G. L., Fraley, R. T., and Chilton, M. D. (1986). The hypervirulence of Agrobacterium tumefaciens A281 is encoded in a region of pTiBo542 outside of the T-DNA. J Bacteriol. 168, 1291-1304. doi: 10.1128/jb. 168.3.1291-1301.1986

Kamle, M., Kumar, P., Patra, J. K., and Bajpai, V. K. (2017). Current perspectives on genetically modified crops and detection methods. 3 Biotech 7:219. doi: 10.1007/s13205-017-0809-3

Krens, F. A., Schaart, J. G., van der Burgh, A. M., Tinnenbroek-Capel, I. E., Groenwold, R., Kodde, L. P., et al. (2015). Cisgenic apple trees; development, characterization, and performance. Front. Plant Sci. 27:286. doi: 10.3389/fpls. 2015.00286

Kunkel, T., Niu, Q.-W., Chan, Y.-S., and Chua, N.-H. (1999). Inducible isopentenyl transferase as a high-efficiency marker for plant transformation. Nat. Biotechnol. 17, 916-919. doi: 10.1038/12914

Kurokawa, N., Hirai, T., Takayama, M., Hiwasa-Tanase, K., and Ezura, H. (2013). An E8 promoter-HSP terminator cassette promotes the high-level accumulation of recombinant protein predominantly in transgenic tomato fruits: a case study of miraculin. Plant Cell Rep. 32, 529-536. doi: 10.1007/ s00299-013-1384-7

Lincoln, J. E., Cordes, S., Read, E., and Fischer, R. L. (1987). Regulation of gene expression by ethylene during Lycopersicon esculentum (tomato) fruit development. Proc. Natl. Acad. Sci. U.S.A. 84, 2793-2797. doi: 10.1073/pnas. 84.9.2793

Lincoln, J. E., and Fischer, R. L. (1988). Diverse mechanisms for the regulation of ethylene-inducible gene expression. Mol. Gen Genet. 212, 71-75. doi: 10.1007/ BF00322446

Livak, K., and Schmittgen, T. (2001). Analysis of relative gene expression data using realtime quantitative PCR and the $2 \Delta \Delta \mathrm{C}(\mathrm{T})$. Methods 25, 402-408. doi: 10.1006/meth.2001.1262

Lyznik, L. A., Rao, K. V., and Hodges, T. K. (1996). Flp-mediated recombination of FRT sites in the maize genome. Nucleic Acids Res. 24, 3784-3789. doi: 10.1093/ nar/24.19.3784

Ma, B., Chen, J., Zheng, H., Fang, T., Ogutu, C., Li, S., et al. (2015). Comparative assessment of sugar and malic acid composition in cultivated and wild apples. Food Chem.. 172, 86-91. doi: 10.1016/j.foodchem.2014 09.032

Maniatis, T., Fritsch, E. F., and Sambrook, J. (1982). Molecular Cloning: a Laboratory Manual. Cold Spring Harbor, NY: Cold Spring Harbor Laboratory.

Murashige, T., and Skoog, F. (1962). A revised medium for rapid growth and bio assays with tobacco tissue cultures. Physiol. Plant. 15, 473-497. doi: 10.1111/j. 1399-3054.1962.tb08052.x

Nairn, M., Dukan, E., Zehavi, U., and Yaron, L. (1986). The water-sweet aftertaste of neohesperidin dihydrochalcone and thaumatin as a method for determining 
their sweet persistence. Chem. Senses 11, 361-370. doi: 10.1093/chemse/11. 3.361

Nikoleli, G., and Nikolelis, D. (2012). Low Calorie Nonnutritive Sweeteners. Boca Raton, FL: CRC Press, 79-118. doi: 10.1201/b12065-5

Onouchi, H., Nishihama, R., Kudo, M., Machida, Y., and Machida, C. (1995). Visualization of site-specific recombination catalyzed by a recombinase from Zygosaccharomyces rouxii in Arabidopsis thaliana. Mol. Gen. Genet. 247, 653660. doi: 10.1007/BF00290396

Perini, P., Pasquali, G., Margis-Pinheiro, M., De, O., and Revers, L. (2014). Reference genes for transcriptional analysis of flowering and fruit ripening stages in apple (Malus $\times$ domestica Borkh.). Mol. Breed. 34, 829-842. doi: 10.1007/s11032-014-0078-3

Popowich, E. A., Firsov, A. P., Mitiouchkina, T. Y., Filipenya, V. L., Dolgov, S. V., and Reshetnikov, V. N. (2007). Agrobacterium-mediated transformation of Hyacinthus orientalis with thaumatin II gene to control fungal diseases. Plant Cell Tiss. Organ Cult. 90, 237-244. doi: 10.1007/s11240-0079254-Z

Quorin, M., and Lepoivre, P. (1977). Etude de milieux adaptes aux cultures in vitro de prunus. Acta Hortic. 78, 437-442. doi: 10.17660/ActaHortic.1977.78.54

Righetti, L., Djennane, S., Berthelot, P., Cournol, N., Wilmot, K., Loridon, E., et al. (2014). Elimination of the nptII marker gene in transgenic apple and pear with a chemically inducible R/Rs recombinase. Plant Cell Tiss. Organ Cult. 117, 335-348. doi: 10.1007/s11240-014-0443-2

Rogers, S. O., and Bendich, A. J. (1994). "Extraction of total cellular DNA from plants, algae and fungi. D1," in Plant Molecular Biology Manual, eds S. B. Gelvin and R. A. Schilperoort (Dordrecht: Kluwer Academic Publishers).

Schaart, J. G., Krens, F. A., Pelgrom, K. T. B., Mendes, O., and Rouwendal, G. J. A. (2004). Effective production of marker-free transgenic strawberry plants using inducible site-specific recombination and a bifunctional selectable marker gene. Plant Biotechnol. J. 2, 233-240. doi: 10.1111/j.1467-7652.2004. 00067.x

Schestibratov, K., and Dolgov, S. (2005). Transgenic strawberry plants expressing a thaumatin II gene demonstrate enhanced resistance to Botrytis cinerea. Sci. Hortic. 106, 177-189. doi: 10.1016/j.scienta.2005.03.016

Schlaman, H. R. M., and Hooykaas, P. J. J. (1997). Effectiveness of the bacterial gene codA encoding cytosine deaminase as a negative selectable marker in Agrobacterium-mediated plant transformation. Plant J. 11, 1377-1385. doi: 10.1046/j.1365-313X.1997.11061377.x

Sidorova, T., Mikhailov, R., Pushin, A., Miroshnichenko, D., and Dolgov, S. (2017). A non-antibiotic selection strategy uses the phosphomannose-isomerase (PMI) gene and green fluorescent protein (GFP) gene for agrobacterium-mediated transformation of Prunus domestica L. leaf explants. Plant Cell Tiss. Organ Cult. 128, 197-209. doi: 10.1007/s11240-016-1100-8

Sugita, K., Kasahara, T., Matsunaga, E., and Ebinuma, H. (2000). A transformation vector for the production of marker-free transgenic plants containing a single copy transgene at high frequency. Plant J. 22, 461-469. doi: 10.1046/j.1365313X.2000.00745.X

Sugita, K., Matsunaga, E., and Ebinuma, H. (1999). Effective selection system for generating marker-free transgenic plants independent of sexual crossing. Plant Cell Rep. 18, 941-947. doi: 10.1007/s002990050688

Szwacka, M., Burza, W., Zawirska-Wojtasiak, R., Goslinski, M., Twardowska, A., Gajc-Wolska, J., et al. (2012). Genetically modified crops expressing 35SThaumatin II transgene: sensory properties and food safety aspects. Compr.
Rev. Food Sci. Food Saf. 11, 174-186. doi: 10.1111/j.1541-4337.2011. 00178.x

Szwacka, M., Morawski, M., and Burza, W. (1996). Agrobacterium tumefaciensmediated cucumber transformation with thaumatin II cDNA. J. Appl. Genet. 37A, 126-129.

Theologis, A., Oeller, P. W., Wong, L. M., Rottmann, W. H., and Gantz, D. M. (1993). Use of a tomato mutant constructed with reverse genetics to study fruit ripening, a complex developmental process. Dev. Genet. 14, 282-295. doi: $10.1002 /$ dvg.1020140406

Timerbaev, V., Okuneva, A., Pushin, A., and Dolgov, S. (2014). "Production of marker-free transgenic tomato plants using inducible site-specific recombinase and a bifunctional selectable gene," in Proceedings of the 13rd international association of plant biotechnology congress 2014, (Melbourne, VIC: IAPB).

van der Wel, H., and Loeve, K. (1972). Isolation and characterization of Thaumatin I and II, the sweet-tasting proteins from Thaumatococcus daniellii Benth. Eur. J. Biochem. 31, 221-225. doi: 10.1111/j.1432-1033.1972. tb02522.x

Vanblaere, T., Flachowsky, H., Gessler, C., and Broggini, G. A. L. (2013). Molecular characterization of cisgenic lines of apple 'Gala' carrying the Rvi6 scab resistance gene. Plant Biotechnol. J. 12, 2-9. doi: 10.1111/pbi.12110

Vanblaere, T., Szankowski, I., Schaart, J., Schouten, H., Flachowsky, H., Broggini, G., et al. (2011). The development of a cisgenic apple plant. $J$ Biotechnol. 154, 304-311. doi: 10.1016/j.jbiotec.2011.05.013

Vandesompele, J., De Preter, K., Pattyn, F., Poppe, B., Van Roy, N., De Paepe, A., et al. (2002). Accurate normalization of real-time quantitative RT-PCR data by geometric averaging of multiple internal control genes. Genome Biol. 3:RESEARCH0034. doi: 10.1186/gb-2002-3-7-research0034

Vigers, A., Wiedemann, S. K., Roberts, W., Legrand, M., Selitrennikoff, C., and Fritig, B. (1992). Thaumatin-like proteins are antifungal. Plant Science 83, 155-161. doi: 10.1016/0168-9452(92)90074-V

Wang, Y., Yau, Y. A., Perkins-Balding, D., and Thomson, J. G. (2011). Recombinase technology: applications and possibilities. Plant Cell Rep. 30, 267-285. doi: 10.1007/s00299-010-0938-1

Witty, M. (1990). Preprothaumatin II is processed to biological activity in Solanum tuberosum. Biotechnol Lett. 12, 131-136. doi: 10.1007/BF01022429

Yau, Y. Y., and Stewart, C. N. (2013). Less is more: strategies to remove marker genes from transgenic plants. BMC Biotechnol. 13:36. doi: 10.1186/1472-675013-36

Zhao, L., Lu, L., Zhang, L., Wang, A., Wang, N., Liang, Z., et al. (2009). Molecular evolution of the E8 promoter in tomato and some of its relative wild species. J. Biosci. 34, 71-83. doi: 10.1007/s12038-009-0010-x

Conflict of Interest Statement: The authors declare that the research was conducted in the absence of any commercial or financial relationships that could be construed as a potential conflict of interest.

Copyright (c) 2019 Timerbaev, Mitiouchkina, Pushin and Dolgov. This is an openaccess article distributed under the terms of the Creative Commons Attribution License (CC BY). The use, distribution or reproduction in other forums is permitted, provided the original author(s) and the copyright owner(s) are credited and that the original publication in this journal is cited, in accordance with accepted academic practice. No use, distribution or reproduction is permitted which does not comply with these terms. 